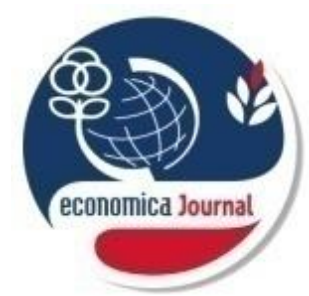

ISSN : $2302-1590$

E-ISSN: $2460-190 X$

\title{
ECONOMICA
}

Jurnal Program Studi Pendidikan Ekonomi

STKIP PGRI Sumatera Barat Vol.9 No.2 (208-217)

\section{SELF EFFICACY AS A DETERMINATION OF STUDENTS ENTREPRENEURIAL INTENTION}

\author{
By \\ Abdul Rahmad ${ }^{1)}$, Kurjono $^{2)}$, Sony Pratama ${ }^{3)}$, Fahmi Zulfikri' $^{4)}$ \\ ${ }^{1)}$ School of Postgraduate Studies, Universitas Pendidikan Indonesia \\ Email: dulrahmad12@upi.edu \\ ${ }^{2)}$ School of Postgraduate Studies, Universitas Pendidikan Indonesia \\ Email: kurjono@upi.edu \\ ${ }^{3)}$ School of Postgraduate Studies, Universitas Pendidikan Indonesia \\ Email: 14sonypratama@upi.edu \\ ${ }^{4)}$ School of Postgraduate Studies, Universitas Pendidikan Indonesia \\ Email: zulfikrifahmi25@upi.edu \\ Submitted: 2020.12.01 Reviewed: 2021.04.03 Accepted: 2021.04.30 \\ https://doi.org/10.22202/economica.2021.v9.i2.4518
}

\begin{abstract}
This study aims at determining and analyzing the effect of self-efficacy on the entrepreneurial interest of students at the Economics Education Study Program, STKIP PGRI, West Sumatera. The method used in this study is a survey with a descriptive quantitative approach. Data collection techniques in this study used a questionnaire using a Likert scale of 1-5. The object of this research is the students of the Economics Education Study Program at STKIP PGRI West Sumatera by determining the sample using the Slovin formula. The data analysis used in this study is a simple linear regression analysis which aims to determine the test of the effect of this research variable in the form of selfefficacy on student interest in entrepreneurship. The results of the research that has been conducted reveal that selfefficacy of students has a significant effect on the interest in entrepreneurship with a confidence level of 5\% and the results of the research prove that the significant value is 0,000 which indicates that the value is less than 0.05. Based on these results, efforts need to be made to increase the entrepreneurial intention of students of the Economics Education Study Program at STKIP PGRI West Sumatera, one of which is by providing facilities and infrastructure that support entrepreneurial activities.
\end{abstract}

Jel Classification:

L31;L30

Keyword: self-efficacy, entrepreneurial interest 


\section{INTRODUCTION}

Entrepreneurial intention leads to the intention to engage in entrepreneurial behavior (Nyock Ilouga, Nyock Mouloungni, and Sahut, 2014). Entrepreneurial intention is defined as a representation of cognitive actions that will be carried out by individuals, either independently or to create new value in an existing company (Bull and Willard, 2012). This problem is thought to be caused by the low interest in entrepreneurship itself. This lack of interest in entrepreneurship arises from the wrong entrepreneurial paradigm in the understanding of Indonesian society. This research is in line with what was carried out by (Bida 2019) concerning The Effect Of Kewira Education, The Need For Achievement, And Self Efficiency Toward the Intention Of Entrepreneurs Students Of Sma Muhammadiyah I Jakarta. Then what is the difference from this study is the analysis of the variables, namely about the need for achievement

Entrepreneurship is considered the last choice in a career. As stated by Leroy, et al, that a person's tendency to do or not do something, such as choosing entrepreneurship as a career, can be predicted by the Theory of Planned Behavior (TPB). TPB uses three pillars as antecedents of intention, namely attitude. on behavior, subjective norms, and perceptions of the ability to control everything that affects the behavior (Budi et al., 2012).

The dynamics of anxiety in facing a behavior in terms of cognitive occurs because of a negative perception of a person's abilities such as feeling unprepared, feeling unable to face obstacles, unable to control physical responses, and this causes anxiety to do a job.

Self-efficacy is self-assessment, whether you can do good or bad actions, right or wrong, you can or can't do what is required. Self-efficacy is different from aspirations (ideals) because ideals describe something ideal that should be achieved, while efficacy represents an assessment of self-ability (Khotimah, Radjah, and Handarini, 2016). This concept refers to the consideration of how much a person believes in his ability to perform several activities and his ability to complete tasks.

Entrepreneurial actions can be defined as deliberate behavior, and this is related to intentionality, namely the existence of a state of mind that leads to attention, experience, and action towards certain goals (Colm O'Gorman, 2019). Entrepreneurship is a process of applying creativity and innovation to solve problems and seek opportunities faced by individuals in a business process (Filipe M. Santo, 2012). A person who has an entrepreneurial spirit must be built based on basic principles, namely a strong ability to work in the economic field, an independent spirit, able to make the right decisions, dare to take risks, creative, innovative, diligent, thorough, and productive, work with a spirit of togetherness, and healthy business ethics (Ranchordas, 2015).

Currently, Indonesia is still experiencing unemployment problems because the large workforce is not proportional to the number of available jobs (Santy, Rahmawati, and Hamzah, 2017). The growth in the number of workers continues to increase. The increase in the number of workers has not been matched by the availability of employment opportunities. Due to the abundance of job seekers and the lack of job vacancies, companies that need employees tend to set quite high-quality standards for human resources (Lanna, 2013). The table regarding the open unemployment rate (TPTTingkat Pengangguran Terbuka) based on education completed in February 2017August 2018 is presented in Table 1.

\section{Table 1. Data on the level of open unemployment (TPT) based on education completed in}




\section{February 2017- August 2018}

\begin{tabular}{cccccc}
\hline & Highest education completed & $\mathbf{2 0 1 7}$ & $\mathbf{2 0 1 7}$ & $\mathbf{2 0 1 8}$ & $\mathbf{2 0 1 8}$ \\
No & & (February) & (August) & (February) & (August) \\
\hline $\mathbf{1}$ & No/Not in school yet & 92,331 & 62,984 & 42,039 & 31,774 \\
$\mathbf{2}$ & No/Not finished Elementary & 546,897 & 404,435 & 446,812 & 326,962 \\
& School yet & & & \\
$\mathbf{3}$ & Elementary School & $1,292,234$ & 904,561 & 967,630 & 898,145 \\
$\mathbf{4}$ & Junior High School & $1,281,240$ & $1,274,417$ & $1,249,761$ & $1,131,214$ \\
$\mathbf{5}$ & Senior High/High School & $1,552,894$ & $1,910,829$ & $1,650,636$ & $1,930,320$ \\
$\mathbf{6}$ & Vocational High School & $1,383,002$ & $1,621,402$ & $1,424,428$ & $1,731,743$ \\
$\mathbf{7}$ & Academics/Diploma & 249,705 & 242,937 & 300,845 & 220,932 \\
$\mathbf{8}$ & University & 606,939 & 618,758 & 789,113 & 729,601 \\
& Total & $\mathbf{7 , 0 0 5 , 2 6 2}$ & $\mathbf{7 , 0 0 5 , 2 6 2}$ & $\mathbf{6 , 8 7 1 , 2 6 4}$ & $\mathbf{7 , 0 0 0 , 6 9 1}$
\end{tabular}

Source: Central Bureau of Statistics, 2018

The following data on the Open Unemployment Rate (TPT) for the period from February 2018 to August 2018 based on the education completed revealed that the level of education in February 2018, the open unemployment rate for vocational high schools (SMK) was the highest among other educational levels, namely $20.73 \%$ and experienced an increase of $4 \%$ in August amounted to $24.73 \%$. The second-highest rate was in Senior High School (SMA) of $24.02 \%$ and experienced an increase of 3\% in August of $27.57 \%$. At the University level, it decreased by $2 \%$ in August (BPS, 2018). The data shows that the highest open unemployment rate is contributed by high school and vocational high school graduates. Every year, public or private education units graduate a large number of alumni, so that if they are not properly absorbed, the number of unemployed people will increase.

The Central Bureau of Statistics (BPS) of West Sumatera Province in February 2019, explained that the highest Open Unemployment Rate (TPT) was in the Diploma and University education group, namely (7.21\%). Meanwhile, the unemployment rate at SMA and SMK is $(3.60 \%)$ and junior high school is below
(2.58\%). This data shows that Diploma and University graduates are not able to meet job demands and have no interest in entrepreneurship. Entrepreneurship plays an important and strategic role in the economic growth of a region, so it is hoped that it will further expand job opportunities about efforts to reduce the unemployment rate (Kristiyanti, 2012).

Cultivating the entrepreneurial spirit of college students is believed to be an alternative way to reduce the rate of unemployment because scholars are expected to become educated young entrepreneurs who can start their businesses (Olorundare \& Kayode, 2014).

One of the alternatives to solve the problems of unemployment and poverty above is by empowering the community through entrepreneurship programs at least $2 \%$ of the total population in the country. Entrepreneurship in Indonesia can still be said to be quite low. In 2019, only $0.2 \%$ of the population were entrepreneurs. Indonesia still needs a lot of stimuli to increase the number of entrepreneurs. At least 4.8 million entrepreneurs are needed so that Indonesia can become a developed country.

The Office of Cooperatives, SMEs, Industry, and Trade (2017) in Indonesia, 
conducted an economic survey in the field of the last education of 256,271 entrepreneurs in Indonesia, and the majority of which are high school graduates (SMA), namely (55\%), while entrepreneurs who received the latest education up to junior high school is $27 \%$, vocational high school (SMK) is 9\%, Higher Education is 8\%, and Elementary School (SD) is $1 \%$, which have been presented in Figure 1.

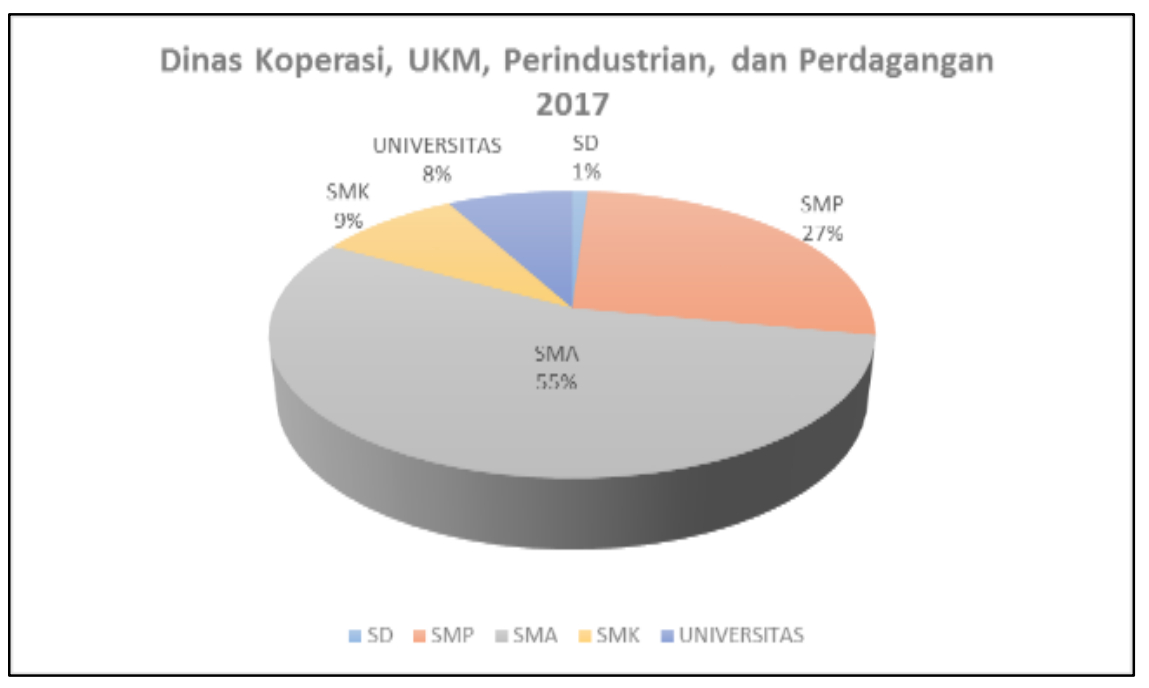

Source: Office of Cooperatives, SMEs, Industry, and Trade (2017)

Figure 1. Percentage of Entrepreneurs in Indonesia

The awareness of entrepreneurship is mostly found in Senior High School graduates. This problem shows that the entrepreneurial intention of college graduates is still low, even though college graduates have been equipped with entrepreneurship courses, seminars, and entrepreneurial practices to foster an entrepreneurial spirit. One of the factors driving the growth of entrepreneurship in a country lies in the role of higher education through the implementation of entrepreneurship education (Kanonuhwa., 2012). The higher education institution is responsible for educating and providing entrepreneurial skills to its graduates and providing motivation to have the courage to have entrepreneurship as their career. The Directorate General of Higher Education, Ministry of Education and Culture (Dirjen Dikti Kemendikbud 2015) supports the development of entrepreneurial programs for students (PMW- program wirausaha bagi mahasiswa) to be implemented and developed by public or private universities. PMW aims to provide knowledge, skills, attitudes, and an entrepreneurial spirit (Entrepreneurship) based on science and technology for students to change their mindset from focusing on looking for jobs to creating jobs.

This program is also expected to reduce unemployment rates for college graduates (Kemendikbud, 2015). Based on Forlap Ristekdikti (2019), the number of students of Economics Education Study Program, STKIP PGRI West Sumatera, is bigger than the number of students in other universities that have the same study program, namely 913 people or $56 \%$, while in Padang State University is $30 \%$, in Eka Sakti University is $6 \%$, in Maha Muh Yamin Solok University is $5 \%$ and finally in National STKIP is $3 \%$.

STKIP PGRI West Sumatera as one of the educational institutions in West Sumatera has long equipped its students to become entrepreneurs with entrepreneurship courses, especially students who take the Economics Education Study Program, not only entrepreneurship courses but students are also 
taught courses that can support entrepreneurial activities for students. Even though they have been equipped with supportive knowledge the interest in entrepreneurship among STKIP PGRI West Sumatra students is still very low as presented in the following Table 2 .

Table 2. Number of Economics Education Study Program Students Graduates 2014 - 2016 who Has Worked

\begin{tabular}{lccccc}
\hline $\begin{array}{c}\text { Graduation } \\
\text { Year }\end{array}$ & $\begin{array}{c}\text { Total } \\
\text { University } \\
\text { Student }\end{array}$ & $\begin{array}{c}\text { Private } \\
\text { sector } \\
\text { Company }\end{array}$ & $\begin{array}{c}\text { Occupation } \\
\text { Government } \\
\text { Company }\end{array}$ & $\begin{array}{c}\text { Self- } \\
\text { employed }\end{array}$ & Teacher \\
\hline 2017 & 31 & 20 & 3 & 6 & 2 \\
2018 & 104 & 82 & 6 & 2 & 14 \\
2019 & 100 & 33 & 33 & 11 & 23 \\
Total & $\mathbf{2 3 5}$ & $\mathbf{1 3 5}$ & $\mathbf{4 2}$ & $\mathbf{1 9}$ & $\mathbf{3 9}$ \\
\hline
\end{tabular}

Source: UNAKERSTKIP PGRI West Sumatera, 2019

The interest of the alumni of the Economics Education Study Program for entrepreneurship is still low. It can be seen from the number of students who become entrepreneurs, only 19 out of 235 students or only $19 \%$ who own their businesses. So I can conclude that there is a lack of business interest in the students of the Economics Education Study Program. The problems in West Sumatera Province are, first, the heavy dependence on the oil palm, tin, and field sectors makes the regional economy more vulnerable when global fluctuations occur.

Second, the location of the region is in the archipelago and is not directly connected to the Java region, making it a strategic role for the connectivity infrastructure in cutting the supply chain for the distribution of goods. Third, the level of regional labor productivity is still low compared to the national average productivity. And fourth, the development of micro and small businesses and also the tourism sector is not optimal.

The approach used in overcoming the low entrepreneurial intention is Theory Planned Behavior which states that a person's intention determines a behavior which consists of three determinants, namely: attitudes towards behavior, subjective norms, and conscious behavior control (Ajzen, 2015, p. 126).
According to Shirokova et al. (2015, p.6) in Zulfickar and Sobandi (2020), there are 3 dimensions/indicators of entrepreneurial intentions, namely: 1. Desires 2. Preferences 3. Plans. Meanwhile, according to (Liñán, F., $\&$ Chen, 2009, p.4), they suggest entrepreneurial intentions can be measured using the following six indicators: 1) Ready to do everything to become an entrepreneur, 2) My professional goals to become an entrepreneur, 3) I will face every obstacle to start and run my own business, 4) I determined to create a business in the future, 5) I am very serious about starting a business, 6) I have a strong interest in starting a new business. The following are dimensions and indicators of entrepreneurial interest that will be used in this study using dimensions from Shirokova et al., (2015).

Based on the problems that have been presented, the purpose of this article is to determine and analyze the effect of selfefficacy on entrepreneurial interest in students of the economics education study program at STKIP PGRI West Sumatera. This study aims at determining and analyzing the effect of selfefficacy on the entrepreneurial interest of students at the Economics Education Study Program, STKIP PGRI, West Sumatera

\section{METHODS}


The sampling technique used was proportional random sampling. According to (Sugiyono, 2016), that: "proportional random sampling technique is a technique of determining a sample from a random population without paying attention to the strata in the members of the population." This is because the population used in this study is relatively small, from 105 people or research that wants to make generalizations with very small errors. So the sample studied was 83 students of economic education at STKIP PGRI West Sumatra. The place where the research was carried out was used as a respondent in this study, namely Student Entrepreneurship at STKIP PGRI West Sumatra with The method used in this research is a survey. According to Sugiyono (2016), a survey is a method used in research by using a questionnaire to collect information. This study uses a quantitative approach. The population in this study are students of economics education at STKIP PGRI West Sumatera with the sampling technique using the Solvin formula, namely as follows:
Description:

$\mathrm{Nt}=$ total sample size drawn

$\mathrm{N}=$ research population

$\mathrm{e}=$ precision (is set $5 \%$ by $95 \%$ of confidence level)

The total sample in this study was 83 students of economics education, with the data collection technique by using a questionnaire. The data analysis used in this study is a simple linear regression that aims to determine the self-efficacy of the entrepreneurial interest in students of economics education at STKIP PGRI West Sumatra.

\section{RESULTS AND DISCUSSION}

Description of the research that has been carried out on the calculation of the score of each respondent's answer, so that the results of the respondent's score are obtained in the form of a description of the general description of self-efficacy and entrepreneurial interest in economics education students of STKIP PGRI West Sumatra which is presented in Figure 2 below.

$$
\mathrm{Nt}=\frac{N}{1+N(e)^{2}}
$$

\section{Self-Efficacy of Economic Education Study Program Students at STKIP PGRI West Sumatera}

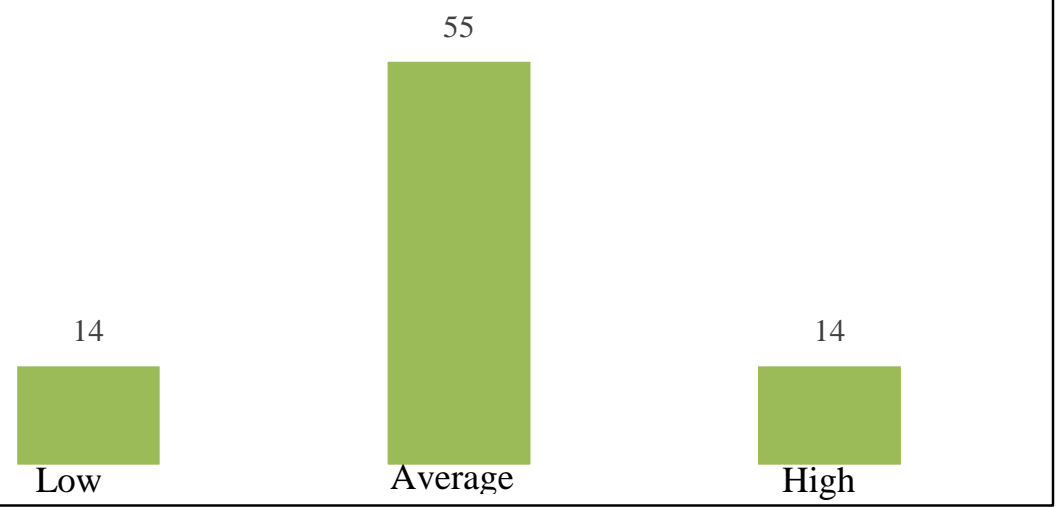

Source: Results of Data Processing (2020)

Figure 2. Self-Efficacy of Economics Education Study Program Students STKIP PGRI West Sumatera 
Based on Figure 2 above, it can be interpreted that students who have selfefficacy in carrying out entrepreneurial intentions have a percentage of $17 \%$ or a total of 14 students out of 83 students who are in the high category. Meanwhile, students who have self-efficacy in implementing entrepreneurial intentions have the lowest percentage of $17 \%$ or with a total of 14 students out of 83 students studied where the highest percentage is selfefficacy in carrying out moderate entrepreneurial intentions of $66 \%$ or with the number of 55 students from 83 students studied.

The results of this study also indicate that self-efficacy has a positive and significant effect on entrepreneurial intentions. Meanwhile, an overview of the Economics Education Study Program students' interest in entrepreneurship at STKIP PGRI West Sumatera is presented in Figure 3 below.

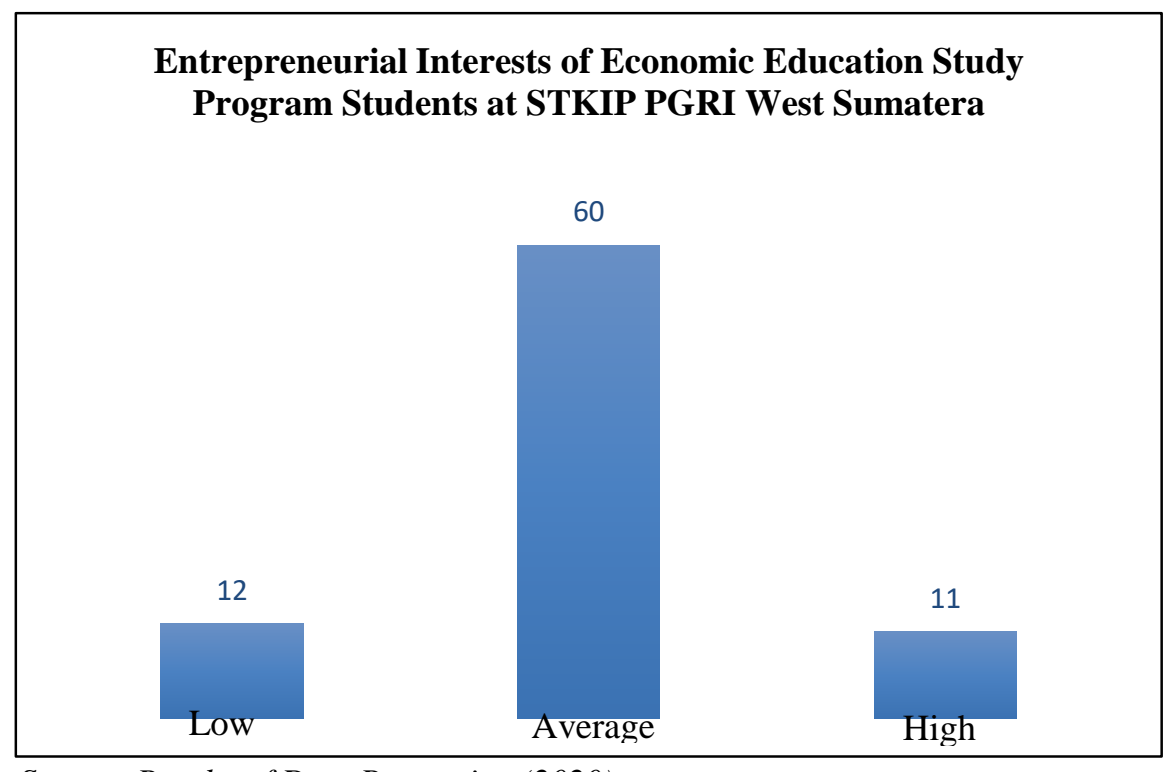

Source: Results of Data Processing (2020)

Figure 3. Entrepreneurial Interests of Economics Education Study Program Students STKIP PGRI West Sumatra

Based on the image of the research results above, it can be interpreted that students who have an interest in entrepreneurship, in carrying out entrepreneurial intentions, have a percentage of $15 \%$ or a total of 12 students out of 83 students who are in the high category. Meanwhile, students who have self-efficacy in implementing entrepreneurial intentions have the lowest percentage of $17 \%$ or with a total of 14 students out of 83 students studied where the highest percentage is self-efficacy in carrying out moderate entrepreneurial intentions of $66 \%$ or with the number of 55 students from 83 students studied. 
Table 3. Simple Linear Regression Statistical Test

\begin{tabular}{|c|c|c|c|c|c|c|}
\hline \multicolumn{7}{|c|}{ Coefficients } \\
\hline & \multirow{3}{*}{ Model } & \multirow{2}{*}{\multicolumn{2}{|c|}{$\begin{array}{l}\text { Unstandardized } \\
\text { Coefficients }\end{array}$}} & \multirow{3}{*}{$\begin{array}{c}\text { Standardized } \\
\text { Coefficients } \\
\text { Beta } \\
\end{array}$} & \multirow{3}{*}{$\mathrm{t}$} & \multirow{3}{*}{ Sig. } \\
\hline & & & & & & \\
\hline & & $\mathrm{B}$ & Std. Error & & & \\
\hline \multirow[t]{2}{*}{1} & (Constant) & 21,352 & 3,606 & & 5,921 & .000 \\
\hline & Self-Efficacy & 523 &, 067 &, 657 & 7,837 & .000 \\
\hline
\end{tabular}

a. Dependent Variable: Entrepreneurial Interest

Source: Results of Data Processing (2020)

Based on hypothesis testing, it is known that self-efficacy has a significant effect on the entrepreneurial interest of students in the Economics Education Study Program. This is evidenced by the results of the research which states that the $t_{\text {count }}$ of 7.837> $\mathrm{t}_{\text {table }} 1.66462$ is significant at 0.000 $<0.05$, which means that $\mathrm{H}_{0}$ is rejected and $\mathrm{H}_{\mathrm{a}}$ is accepted. Based on the descriptive test results, it shows that self-efficacy is in a good category. This shows that students of the Economics Education Study Program have good confidence or self-confidence to generate interest in entrepreneurship in students. According to Bandura, self-efficacy refers to an individual's belief in his or her ability to mobilize the motivation, cognitive resources, and actions needed to successfully carry out a task in a particular context. Highefficacy individuals focus on opportunities that are worth pursuing and see obstacles as those that can be overcome. Individuals with high self-efficacy will inevitably expect success and get the desired and incentivized positive results.

The researcher on the research result assumes that there is an effect of self-efficacy on the interest in entrepreneurship in the Economics Education Study Program of STKIP PGRI West Sumatera. This is because if students have confidence in their entrepreneurial abilities, they will be interested in becoming entrepreneurs, and vice versa that if students lack confidence in entrepreneurial skills, it will affect students' interest in entrepreneurship.

\section{CONCLUSION}

Nowadays, the urgency of one of the alternatives to solve the problems of unemployment and poverty above is to empower the community, including students, who are agents of change in one place, one of which is through entrepreneurship program activities (entrepreneurship). Based on the results of the research that has been done, it is revealed that the self-efficacy of students in the economics education study program has a significant effect on the interest in entrepreneurship with a confidence level of $5 \%$ and the results of the research prove that the significant value is 0.000 which indicates that the value is less than 0.05 with the percentage value of efficacy. Students of the Economics Education Study Program at STKIP PGRI West Sumatera are more dominant in the medium category with a percentage value of $66 \%$ or 55 people out of 83 samples studied while the percentage value of entrepreneurial interest is also in the medium category with a total of $72 \%$ or 60 students of the 83 students studied.

Based on these data, efforts must be made to increase entrepreneurial intentions for students of the Economics Education Study Program STKIP PGRI West Sumatra based on this research by providing facilities and infrastructure supporting entrepreneurial activities. For example, entrepreneurship teaching is not only focused on the cognitive realm, but also on "experiencing" activities as well as practice-based learning. Thus, 
lecturers who teach entrepreneurship courses should continue to be creative in creating learning models that accommodate students to stimulate and encourage their creativity.

\section{REFERENCES}

Ajzen, I. (2015) 'Consumer attitudes and behavior: the theory of planned behavior applied to food consumption decisions', Consumer attitudes and behavior: the theory of planned behavior applied to food consumption decisions, 70(2), pp. 121-138. doi: 10.13128/REA-18003.

Bida Sari. (2019). Pengaruh Pendidikan Kewira, Kebutuhan Akan Prestasi Dan Efikasi Diri Terhadap Intensi Berwirausaha Siswa Sma Muhammadiyah I Jakarta. jurnal IKRAITH-EKONOMIKA Vol 2 No 1

BPS, B. P. S. (2018) 'Statistik', (42), pp. 116.

Budi, R. et al. (2012) 'Pengaruh Pendidikan Kewirausahaan Terhadap Minat Berw irausaha Mahasiswa di STIE MDP, STMIK MDP, dan STIE MUSI', Forum Bisnis Dan Kewirausahaan Jurnal Ilmiah STIE MDP Hal -112, 1(2), pp. 112-119.

Bull, I. and Willard, G. E. (2012) 'Towards a theory of entrepreneurship', Journal of Business Venturing, 8(3), pp. 183-195. doi: 10.1016/0883-9026(93)90026-2.

Kemendiknas, 2015. "Entrepreneurship Education Development In Dealing Asean Economic

Community." Proceeding

International Conference on Mathematic, Science, Technology, Education and their Applications. Vol. 1. No. 1. 2016.

Felipe Mendes Borini. Startups and Innovation Ecosystems in Emerging
Markets. Springer, 2019.

Forlap Ristekdikti (2019) "The Effect of Proactive Personality on Entrepreneurial Intention." Proceeding Interuniversity Forum for Strengthening Academic Competency. Vol. 1. No. 1. 2019.

Kanonuhwa, M. et al. (2012) 'The association between emotional intelligence and entrepreneurship as a career choice: A study on university students in South Africa', pp. 1-9.

Khotimah, R., Radjah, C. and Handarini, D. (2016) 'Hubungan Antara Konsep Diri Akademik, Efikasi Diri Akademik, Harga Diri Dan Prokrastinasi Akade mik Pada Siswa Smp Negeri Di Kota Malang', Jurnal Kajian Bimbingan dan Konseling, 1(2), pp. 60-67. doi: 10.17977/um001v1i22016p060.

Kristiyanti, M. (2012) 'Peran Strategis Usaha Kecil Menengah ( UKM ) Dalam Pembangunan Nasional'.

LANNA, F. (2013) 'No 主観的健康感を中 心亡した在宅高齢者における 健康 関連指標に関する共分散構造分析

Title', Jurnal Teknologi, 1(1), pp. 6973. doi: 10.11113/jt.v56.60.

Liñán, F., \& Chen, Y. (2009) 'Development and Cross-Cultural Application of a Specific Instrument to Measure Entrep reneurial Intentions', Entrepreneurshi $p$ Theory and Practice, 33(3), pp. 593617.

Nyock Ilouga, S., Nyock Mouloungni, A. C. and Sahut, J. M. (2014) 'Entrepreneurial intention and career choices: The role of volition', Small Business Economics, 42(4), pp. 717728. doi: 10.1007/s11187-013-9524-6.

O’Gorman, Colm. "Entrepreneurial Intentions and Entrepreneurial Behaviour." Entrepreneurial 
Behaviour (2019): 17-37.

Olorundare, A. S. and Kayode, D. J. (2014) 'Entrepreneurship Education In Nigeri an Universities: A TOOL FOR NATIONAL', 29, pp. 155-175.

Ranchordás, Sofia. "Time, Timing, And Experimental Legislation." (2015): 135-139.

Santy, N., Rahmawati, T. and Hamzah, A. (2017) 'Pengaruh Efikasi Diri, Norma Subjektif, Sikap Berperilaku Dan Pend idikan Kewirausahaan Terhadap Intensi Berwirausaha', Jurnal Inspiras i Bisnis dan Manajemen, 1(1), p. 63. doi: 10.33603/jibm.v1i1.481.

Shirokova, G., Osiyevskyy, O. and Bogatyreva, K. (2015) 'Exploring the intention-behavior link in student entrepreneurship : Moderating effects of individual and environmental characteristics', European Manageme nt Journal. Elsevier Ltd, pp. 1-14. doi: 10.1016/j.emj.2015.12.007.

Sugiyono (2016). "Methode Suceceaive Inte rval (MSI)".Entrepreneurship Educati on In NigeriaUniversities: A TOOL FOR NATIONAL'

UNAKERSTKIP PGRI West Sumatera, 2019

Zulfickar, R. and Sobandi, A. (2020) 'Studi Tentang Pengaruh Latar Belakang Keluarga Terhadap Intensi Kewirausa haan Siswa SMKN Se-Kabupaten Bangka', Edunomic Jurnal Pendidikan Ekonomi, 8(1), p. 20. doi: 10.33603/ej pe.v8i1.2817. 